\title{
Corrosion resistance of mild steel (hull plate) in sea water in the presence of a coating of an oil extract of plant materials
}

\author{
R. Dorothy, ${ }^{1 *}$ T. Sasilatha ${ }^{1}$ and S. Rajendran ${ }^{2}{ }^{(1 *}$
}

${ }^{1}$ Department of EEE, AMET University, Kanathur, East Coast Road, Chennai, India

${ }^{2}$ Corrosion Research Centre, Department of Chemistry, St. Antony's College of Arts and Sciences for Women Thamaraipady, Dindigul-624005, Tamil Nadu, India

*E-mail: contactrdorothy@gmail.com, susairajendran@gmail.com

\begin{abstract}
Mild steel can be used as hull plates in ship industry. Mild steel has to be in contact with sea water which contains aggressive sodium chloride ions to the extent of $3.5 \%$. This leads to severe corrosion problems. To mitigate this corrosion problem an oil coating containing extracts of natural products has been used. The corrosion protection nature of this oil coating has been evaluated by weight loss method which reveals that the oil coating offers $99 \%$ inhibition efficiency to mild steel immersed in natural sea water. The polarization study reveals that the coating acts as a barrier film controlling the anodic reaction predominantly. The corrosion potential is shifted from $-0.875 \mathrm{~V}$ SCE to $-0.611 \mathrm{~V} \mathrm{SCE}$. The linear polarization value increases from $1630 \mathrm{Ohm} \cdot \mathrm{cm}^{2}$ to $9238 \mathrm{Ohm} \cdot \mathrm{cm}^{2} \quad(I E=82.35 \%)$. The corrosion current decreases from $1.918 \times 10^{-5} \mathrm{~A} / \mathrm{cm}^{2}$ to $0.3538 \times 10^{-5} \mathrm{~A} / \mathrm{cm}^{2}(I E=81.55 \%)$. These factors confirm that the oil coating controls the corrosion of hull plates in sea water. The AC impedance spectra confirm that the protective coating is very stable as revealed by the fact that in the presence of coating on mild steel, its charge transfer resistance increases, impedance increases, whereas corrosion current decreases to a great extent. Vickers hardness study confirms that in the presence of sea water, the hardness of mild steel decreases whereas in the presence of coating the hardness of mild steel increases. SEM images of various metal surfaces reveal that in the presence of sea water alone, pits are noticed on mild steel whereas in the presence of oil coating the surface appears to be smooth, when immersed in sea water. When mild steel is immersed in sea water, the contact angle decreases when compared with polished metal. But for oil coated mild steel the contact angle increases, hydrophobicity increases and hence corrosion protection increases. It is suggested that this oil coating containing extracts of plant material may be coated on hull plates made of mild steel to protect them from severe corrosion due to the aggressive ions present in sea water.
\end{abstract}

Keywords: ship corrosion, hull plates, mild steel, oil containing extracts of natural products, green inhibitors.

Received: April 16, 2021. Published: May 21, 2021

doi: $\underline{10.17675 / 2305-6894-2021-10-2-13}$ 


\section{Introduction}

In ship industry, the corrosion caused by sea water on the hull plates made of mild steel is a major issue. Hence several studies have been reported on the measures taken to control corrosion of metals and alloys in sea water. Shen et al. have made a study of pitting corrosion inhibition effect on aluminum alloy in seawater by biomineralized film. The electrochemical results showed that the radius of the impedance arc of the alloy immersed in seawater with bacteria increased gradually with time. The bacteria promoted the formation of the $\mathrm{CaMg}\left(\mathrm{CO}_{3}\right)_{2}$ film, which blocked seawater from the alloy and consequently, inhibited pitting corrosion [1]. Xu et al. have investigated steel rebar corrosion in artificial reef concrete with sulphoaluminate cement. It has been observed that a $2 \%$ dosage of corrosion inhibitor can significantly decrease the steel rebar corrosion in a new artificial reef concrete (NARC) to a similar corrosion degree of ordinary artificial reef concrete (ARC) [2]. Colloidal $\mathrm{ZrO}_{2}$ nanoparticles have been used for corrosion protection of AA2024 in synthetic sea water by Elbasuney et al. Inhibition efficiency of $93.6 \%$ was achieved. It was noted that $\mathrm{ZrO}_{2}$ could act as cathodic inhibitor by suppressing the dealloying of the intermetallic particles [3]. In marine conditions, especially in the Arctic, the problems of reliability and safety of marine corrosion protection systems are relevant. Reliability can be enhanced by corrosion inhibitors. Phosphating compound with anode inhibitors have been used by Plaskeeva and Trusov [4]. Duduna et al. have compared various adsorption isotherm models for allium cepa as corrosion inhibitor on austenitic stainless steel in sea water. The sorption data of the allium cepa extract obeyed Langmuir, Freundlich, Temkin, El-Awady and Adejo Ekwenchi isotherm of which Langmuir Isotherm gave the best model fit [5]. Corrosion studies of zinc coated steel parts in sea water have been made by Karthikeyan and Jeeva. The corrosion inhibition of zinc coated steel sheets immersed in $3.5 \% \mathrm{NaCl}$ with sulfisoxazole (SSZ) has been reported by weight loss, potentiodynamic polarization, electrochemical impedance spectroscopy, hydrogen permeation studies and quantum mechanical studies. Polarization studies confirmed that the inhibition mode follows a mixed type. The adsorption of the compounds onto the zinc coated steel surface obeyed Langmuir adsorption isotherm [6]. Managing corrosion in desalination plants has been discussed by Schorr et al. To protect the desalination plant (DP) materials, industrial paints, polymeric coatings and rubber linings compatible with the DP fluids are applied. Cathodic protection with sacrificial anodic metals or impressed direct electrical current and corrosion inhibitors are supplied [7]. Influence of inhibitors on reinforced bar corrosion of coral aggregate seawater concrete has been investigated by Da et al. The effect of inhibitors on corrosion behavior of reinforced bar in coral aggregate seawater concrete (CASC) in artificial sea water was studied by means of linear polarization resistance method (LPR) and electrochemical impedance spectroscopy (EIS). Two inhibitors, calcium nitrite rust inhibitor $(\mathrm{CN})$ and amino-alcohol rust inhibitor (AA) are used. The effect of inhibitors on corrosion behavior of reinforced bar in coral aggregate seawater concrete (CASC) in artificial sea water was studied by means of linear polarization resistance method (LPR) and electrochemical impedance spectroscopy (EIS) 
[8]. Ahmad et al. have reported synthesis, identification, theoretical and experimental studies for carbon steel corrosion inhibition in sea water for new urea and thiourea derivatives linkage to 5-Nitro Isatin Moiety. Isatin derivative has been chosen as the best inhibitor by polarization study [9]. Evaluation of leaf and bark extracts of Acacia tortilis as corrosion inhibitors for mild steel in seawater has been reported by Ali et al. Polarisation study reveals that the extracts act as mixed type inhibitors. AC impedance spectra confirm the formation of a protective layer on the metal surface. The adsorption of the inhibitors on the steel surface follow Langmuir adsorption isotherm model [10].

The present study is undertaken to investigate the corrosion resistance of mild steel, which is used in the manufacture of hull plates, immersed in sea water, in the absence and presence of an oil coating containing plant extracts. The corrosion inhibition efficiency has been evaluated by weight loss method. The mechanistic aspects of corrosion inhibition have been studied by polarization study and AC impedance spectra. The protective film has been analyzed by FTIR spectroscopy. The surface morphology has been investigated by SEM. The hardness of the metal surface has been measured. The contact angle of various surfaces has been found out to know the hydrophobic nature of the various surfaces.

\section{Experimental}

\section{Composition of mild steel}

The composition of mild steel is given in Table 1. This mild steel is used in the construction of hull plates.

Table 1. Composition of mild steel.

\begin{tabular}{cccccc}
\hline Element & Average, $\%$ & Abs. Std. Dev. & Ref. Std. Dev. & $\mathbf{1}$ & $\mathbf{2}$ \\
\hline $\mathrm{C}$ & 0.101 & 0.0014 & 1.4 & 0.102 & 0.1 \\
$\mathrm{Si}$ & 0.055 & 0.0021 & 3.89 & 0.053 & 0.056 \\
$\mathrm{Mn}$ & 1.629 & 0.0057 & 0.35 & 1.633 & 1.625 \\
$\mathrm{P}$ & 0.0087 & 0.0003 & 3.25 & 0.0085 & 0.0089 \\
$\mathrm{~S}$ & 0.0028 & 0.0003 & 10.1 & 0.0026 & 0.003 \\
$\mathrm{Cr}$ & 0.036 & 0.0014 & 3.93 & 0.037 & 0.035 \\
$\mathrm{Mo}$ & 0.0086 & 0.00007 & 0.83 & 0.0086 & 0.0085 \\
$\mathrm{Ni}$ & 0.033 & 0.0007 & 2.18 & 0.033 & 0.32 \\
$\mathrm{Cu}$ & 0.0063 & 0.00007 & 1.13 & 0.0062 & 0.0063 \\
$\mathrm{Al}$ & 0.044 & 0.0014 & 3.21 & 0.043 & 0.045 \\
$\mathrm{As}$ & 0.0011 & 0 & 0 & 0.0011 & 0.011 \\
$\mathrm{~B}$ & 0.0027 & 0.0005 & 18.68 & $<0.00010$ & $<0.00010$ \\
\hline
\end{tabular}




\begin{tabular}{|c|c|c|c|c|c|}
\hline Element & Average, \% & Abs. Std. Dev. & Ref. Std. Dev. & 1 & 2 \\
\hline $\mathrm{Bi}$ & $<0.00010$ & 0.00002 & 84.85 & $<0.0025$ & 0.003 \\
\hline $\mathrm{Ce}$ & 0.0032 & 0.0013 & 42.65 & 0.0041 & 0.0022 \\
\hline Co & 0.011 & 0 & 0 & 0.011 & 0.011 \\
\hline $\mathrm{Mg}$ & 0.0003 & 0 & 0 & 0.0003 & 0.0003 \\
\hline $\mathrm{Nb}$ & 0.03 & 0.0007 & 2.4 & 0.029 & 0.03 \\
\hline $\mathrm{Pb}$ & 0.0081 & 0.0013 & 15.71 & 0.0072 & 0.009 \\
\hline $\mathrm{Sb}$ & 0.004 & 0.0004 & 8.95 & 0.0037 & 0.0042 \\
\hline $\mathrm{Sn}$ & 0.0034 & 0 & 0 & 0.0034 & 0.0034 \\
\hline $\mathrm{Ta}$ & 0.03 & 0.0071 & 23.57 & 0.025 & 0.035 \\
\hline $\mathrm{La}$ & 0.0071 & 0 & 0 & 0.0071 & 0.0071 \\
\hline $\mathrm{Ti}$ & 0.0035 & 0 & 0 & 0.0035 & 0.0035 \\
\hline $\mathrm{V}$ & 0.138 & 0.0014 & 1.02 & 0.137 & 0.139 \\
\hline W & 0.071 & 0,0078 & 11.03 & 0.076 & 0.065 \\
\hline $\mathrm{Zn}$ & 0.0024 & 0 & 0 & 0.0024 & 0.0024 \\
\hline $\mathrm{Zr}$ & 0.0051 & 0.0002 & 0.2 & 0.0052 & 0.0049 \\
\hline $\mathrm{Se}$ & $<0.0005$ & 0.0001 & 4.42 & $<0.0005$ & $<0.0005$ \\
\hline $\mathrm{N}$ & 0.0093 & 0.00007 & 0.76 & 0.0092 & 0.0093 \\
\hline $\mathrm{Ca}$ & 0.0014 & 0.0001 & 10.1 & 0.0013 & 0.0015 \\
\hline $\mathrm{Te}$ & 0.0026 & 0.0025 & 97.91 & $<0.0010$ & 0.0044 \\
\hline $\mathrm{Fe}$ & 97.74 & 0 & 0 & 97.74 & 97.74 \\
\hline
\end{tabular}

Sea water

The corrosion resistance of mild steel in sea water was investigated, before oil coating and after oil coating. The composition of sea water used in this study is given in Table 2. Sea water was collected in Bay of Bengal, located at Kanampadi, East Coast Road, Chennai, India (near AMET University, Kanampadi, East Coast Road, Chennai, India).

Table 2. Composition of sea water used in this study (all the values, except $\mathrm{pH}$, are in ppm).

\begin{tabular}{ccccc}
\hline S. No. & Physical Examination & $\begin{array}{c}\text { Acceptable } \\
\text { Limit }\end{array}$ & $\begin{array}{c}\text { Permissible } \\
\text { limit }\end{array}$ & Sample Value \\
\hline 1 & Colour & - & - & Unobjectionable \\
2 & Odour & Unobjectionable & Unobjectionable & \\
3 & Turbidity NT Units & 1 & 5 & 0.2 \\
\hline
\end{tabular}




\begin{tabular}{|c|c|c|c|c|}
\hline S. No. & Physical Examination & $\begin{array}{l}\text { Acceptable } \\
\text { Limit }\end{array}$ & $\begin{array}{l}\text { Permissible } \\
\text { limit }\end{array}$ & Sample Value \\
\hline 4 & $\begin{array}{l}\text { Total Dissolved Solids } \\
\mathrm{mg} / 1\end{array}$ & 500 & 2000 & 29400 \\
\hline 5 & $\begin{array}{l}\text { Electrical Conductivity } \\
\text { micro } \mathrm{mho} / \mathrm{cm}\end{array}$ & - & - & 42000 \\
\hline 6 & $\mathrm{pH}$ & $6.5-8.5$ & $6.5-8.5$ & 7.46 \\
\hline 7 & pH Alkalinity as $\mathrm{CaCO}_{3}$ & - & 0 & 0 \\
\hline 8 & $\begin{array}{l}\text { Total Alkalinity as } \\
\mathrm{CaCO}_{3}\end{array}$ & 200 & 600 & 140 \\
\hline 9 & Total Hardness as $\mathrm{CaCO}_{3}$ & 200 & 600 & 4000 \\
\hline 10 & Calcium as $\mathrm{Ca}$ & 75 & 200 & 1200 \\
\hline 11 & Manganese as Mn & 30 & 100 & 240 \\
\hline 12 & Iron as $\mathrm{Fe}$ & 0.1 & 1 & 0 \\
\hline 13 & Magnesium as Mg & 0.1 & 0.3 & NT \\
\hline 14 & Free Ammonia as $\mathrm{NH}_{3}$ & 0.5 & 0.5 & 0.48 \\
\hline 15 & Nitrite as $\mathrm{NO}_{2}$ & 0.5 & 0.5 & 0.104 \\
\hline 16 & Nitrate as $\mathrm{NO}_{3}$ & 45 & 45 & 25 \\
\hline 17 & Chloride as $\mathrm{Cl}$ & 250 & 1000 & 15000 \\
\hline 18 & Fluoride as F & 1 & 1.5 & 1.8 \\
\hline 19 & Sulphate as $\mathrm{SO}_{4}$ & 200 & 400 & 1170 \\
\hline 20 & Phosphate as $\mathrm{PO}_{4}$ & 0.5 & 0.5 & 1.47 \\
\hline 21 & Tids Test 4 hrs as $\mathrm{O}_{2}$ & - & - & NT \\
\hline
\end{tabular}

Preparation of inhibitor (Oil containing extracts of plant materials)

$5 \mathrm{~g}$ Each of Cardamom (dismbiguation), Clove (dismbiguation), Nutmeg, India Sambrani (loban), Chrysopogon zizanioides, commonly known as vetiver and Camphor were boiled along with sandalwood oil for 15 minutes in an iron vessel. The suspended impurities were removed by filtration. The total volume of the oil extract of the above was $100 \mathrm{ml}$. This oil extract of the plant materials was used in the present study.

The main active ingredients of the above materials are given in Table 3, and their structures are shown in Figure 1. 
Table 3. Ingredients of natural products.

\begin{tabular}{ccc}
\hline S. No. & Natural products & Ingredients \\
\hline 1 & Cardamom & $\alpha$-terpineol, myrcene, 1,8-cineol \\
2 & Clove & Eugenol \\
3 & Nutmeg & Myristicin, tremyristicin, myristic acid \\
4 & India Sambrani (loban) & Benzoin \\
5 & Vetiver & $\alpha$-vetivone, $\beta$-vetivone, khusimol \\
6 & Camphor & $(+)$-Camphor, $(-)$-Camphor \\
7 & sandalwood oil & $\alpha$-santalol, $\beta$-santalol \\
\hline
\end{tabular}

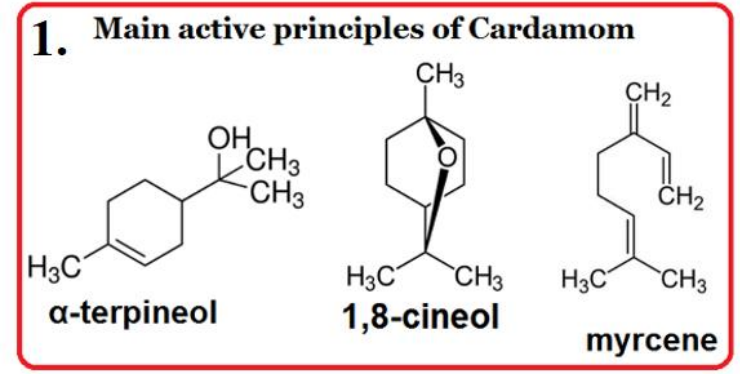

4. main active principles of Nutmeg<smiles>C=CCc1cc(OC)c2c(c1)OCO2</smiles>

myristicin

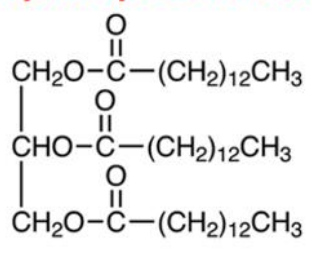

trimyristin

\section{Active ingredient of clove}

$\mathrm{H}_{3} \mathrm{CO}$<smiles>C=CCc1ccc(O)c(CC)c1</smiles>

Eugenol
3. Active principle of India Sambrani or loban

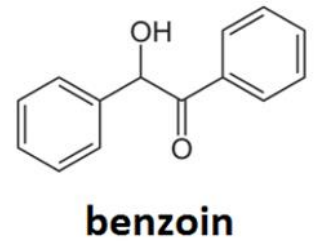

6. Main active principles of vetiver<smiles>CC(C)=C1CCC2=CC(=O)C[C@H](C)[C@]2(C)C1</smiles>

$\alpha$-vetivone<smiles>CC1=CC(=O)C[C@H](C)[C@]12CCC(=C(C)C)C2</smiles>

$\beta$-vetivone

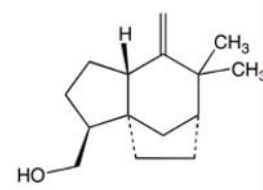

khusimol myristic acid

5. Ingredients of camphor<smiles>CC1(C)[C@H]2CC(=O)[C@]1(C)C2</smiles>

(1R)-(+)-camphor

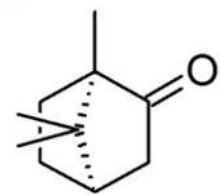

(1S)-(-)-camphor

Figure 1. Ingredients of natural products: 1 - active principles of cardamom; 2 - active principles of clove; 3 - active principles of loban; 4 - active principles of nutmeg; 5 - active principles of camphor; 6 - active principles of vetiver; 7 - active principles of sandalwood oil.

\section{Weight loss method}

Weights of the three polished mild steel specimens were measured before and after immersion in various test solutions. The inhibition efficiencies were calculated from the relation: 


$$
I E=\frac{C R_{1}-C R_{2}}{C R_{1}} \cdot 100 \%,
$$

where $C R_{1}$ is the corrosion rate in the absence of inhibitor and $C R_{2}$ is the corrosion rate in the presence of inhibitor (oil coating).

\section{Electrochemical studies}

In the present work the corrosion resistance of mild steel specimens immersed in various test solutions was measured by Polarization study and AC impedance spectra.

\section{Polarization study}

Polarization studies were carried out in a CHI Electrochemical work station model 660A. It was provided with automatic $i R$ compensation facility. A three electrode cell assembly was used (Figure 2). The working electrode was mild steel. A SCE was the reference electrode. Platinum was the counter electrode. From polarization study, corrosion parameters such as corrosion potential $\left(E_{\text {corr }}\right)$, corrosion current $\left(I_{\text {corr }}\right)$, Tafel slopes anodic $=b_{\mathrm{a}}$ and cathodic $=b_{\mathrm{c}}$ and $L P R$ (linear polarisation resistance) values were derived. The scan rate $(\mathrm{V} / \mathrm{S})$ was 0.01 . Hold time at (Efcs) was zero and quiet time (s) was 2.

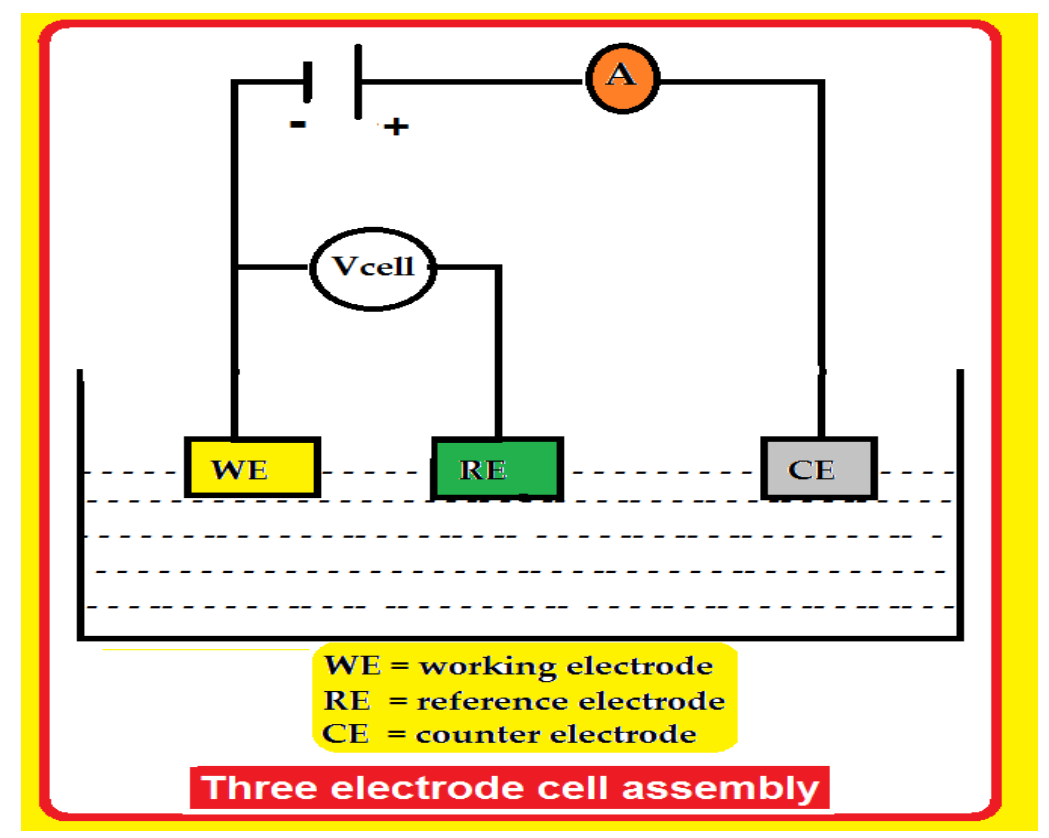

Figure 2. Three electrode cell assembly.

\section{AC Impedance spectra}

The same instrument and set-up used for polarization study was used to record AC impedance spectra also. The real part ( $\left.Z^{\prime}\right)$ and imaginary part $\left(-Z^{\prime}\right.$ ') of the cell impedance were measured in Ohms at various frequencies. AC impedance spectra were recorded with initial $E(\mathrm{~V})=0$, high frequency $\left(1 \times 10^{5} \mathrm{~Hz}\right)$, low frequency $(1 \mathrm{~Hz})$, amplitude $(0.005 \mathrm{~V})$ and 
quiet time $(2 \mathrm{~s})$. From Nyquist plot the values of charge transfer resistance $\left(R_{\mathrm{t}}\right)$ and the double layer capacitance $\left(C_{\mathrm{dl}}\right)$ were calculated.

Surface analysis by FTIR spectra

FTIR spectra were recorded using a Perkin-Elmer 1600 FTIR spectrophotometer with a resolving power of $4 \mathrm{~cm}^{-1}$. In the FTIR spectral study, the following method was adopted. A few drops of the oil extract was placed on a glass plate and dried in the air. The film was carefully scratched with glass rod and mixed with $\mathrm{KBr}$ and made into a pellet. Its FTIR spectrum was recorded. In the next stage, the metal was immersed in the oil extract for one day. After one day, the metal was taken out and dried. The film formed on the metal surface was carefully scratched with glass rod and mixed with $\mathrm{KBr}$ and made into a pellet. Its FTIR spectrum was recorded. Mild steel was immersed in sea water alone for one day. Brown iron oxides were formed. Their FTIR spectrum was recorded.

\section{Scanning Electron Microscopic studies (SEM)}

The surface morphology of various metal surfaces was examined using JEOL MODEL 6390 computer controlled scanning electron microscope.

\section{Contact angle measurement}

Contact angle measurements of various surfaces were measured using Goniometer model G16.

\section{Results and Discussion}

Analysis of results of weight loss method

Corrosion resistance of mild (hull plate) in natural sea water, before and after oil coating has been evaluated by weight loss method. The results are given in Table 4 and Figure 3 .

Table 4. Inhibition of corrosion of mild steel in seawater. Inhibitor system: Oil containing plant extract, Immersion period: 1 day.

\begin{tabular}{cccc}
\hline System & $\begin{array}{c}\text { Corrosion rate } \\
(\mathbf{m d d})\end{array}$ & $\begin{array}{c}\text { Inhibition } \\
\text { efficiency, (\%) }\end{array}$ & Surface coverage ( $\boldsymbol{\theta})$ \\
\hline $\begin{array}{c}\text { Mild steel immersed in Sea } \\
\text { water }\end{array}$ & 16.23 & 0 & 0 \\
$\begin{array}{c}\text { Oil extract coated mild steel } \\
\text { immersed in sea water }\end{array}$ & 0.1623 & 99 & 0.99 \\
\hline
\end{tabular}




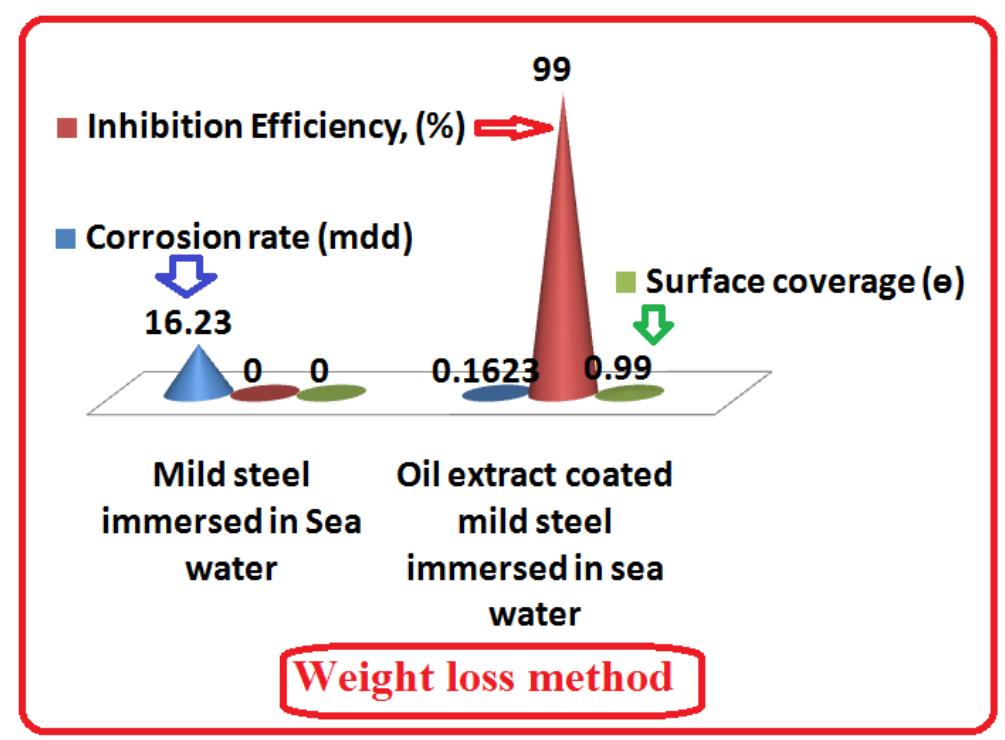

Figure 3. Summary of results of weight loss method.

It is observed from Table 4 that oil coating offers $99 \%$ corrosion protection to mild steel which is used as hull plates.

\section{Implication}

It implies that the hull plates may be coated with the oil containing the plant extract, to protect the metal from corrosion caused by sea water.

\section{Electrochemical studies}

The hull plates of the ship are always in contact with sea water, which contains aggressive ions such as chloride ions. So the hull plates undergo corrosion. To prevent this type of corrosion the hull plates were coated with an oil extract of natural products. The hull plate specimens were made of mild steel as discussed in experimental section. The preparation of the oil extract has also been explained in experimental section. The corrosion resistance of mild steel (hull plate) in sea water before and after coating has been evaluated by weight loss method and electrochemical studies such as polarization study and AC impedance spectra [11-30].

\section{Analysis of polarisation curves}

Polarisation study has been used to detect the formation of protective film on the metal surface. When a protective film is formed on the metal surface, the linear polarisation resistance $(L P R)$ increases and the corrosion current (I) decreases (Figure 4). 


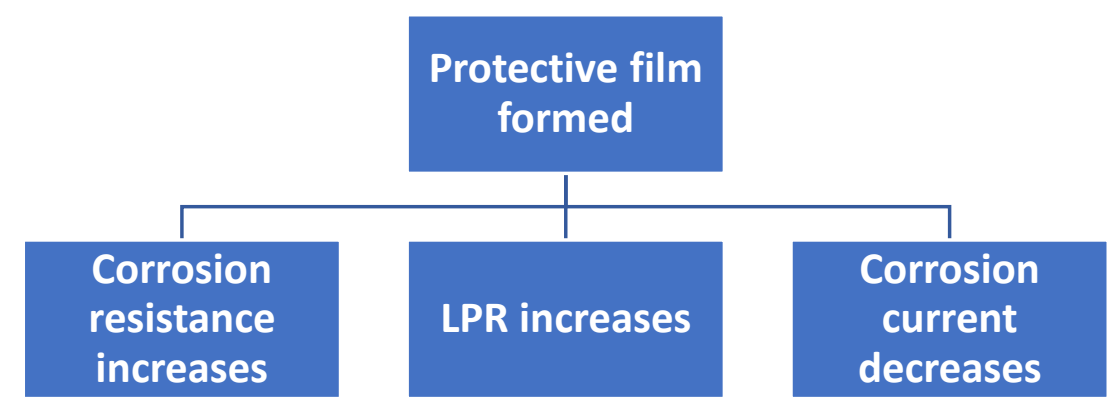

Figure 4. Correlation among corrosion parameters in polarization study.

Corrosion parameters derived from polarisation study, namely corrosion potential $\left(E_{\text {corr }}\right)$, Tafel slopes $\left(b_{\mathrm{c}}, b_{\mathrm{a}}\right)$, Linear Polarisation Resistance $(L P R)$ values and Corrosion Current $\left(I_{\text {corr }}\right)$ values are given in Table 5. The polarisation curves of mild steel (hull plate) immersed in sea water in the absence and presence of oil coating containing plant extract are shown in Figure 5.

Table 5. Corrosion parameters of mild steel (hull plate) immersed in sea water in the absence and presence of oil containing plant extracts, obtained by Polarization study.

\begin{tabular}{cccccc}
\hline System & $\begin{array}{c}\boldsymbol{E}_{\text {corr, }}, \\
\text { VSCE }\end{array}$ & $\begin{array}{c}\boldsymbol{b}_{\mathbf{c}}, \\
\text { V/decade }\end{array}$ & $\begin{array}{c}\boldsymbol{b}_{\text {a, }}, \\
\text { V/decade }\end{array}$ & $\begin{array}{c}\boldsymbol{L P R}, \\
\mathbf{O h m} \cdot \mathbf{c m}^{2}\end{array}$ & $\begin{array}{c}\boldsymbol{I}_{\text {corr, }} \\
\mathbf{A} / \mathbf{c m}^{2}\end{array}$ \\
\hline $\begin{array}{c}\text { Mild steel immersed in sea } \\
\text { water }\end{array}$ & -0.875 & 9.428 & 4.476 & 1630 & $1.918 \times 10^{-5}$ \\
$\begin{array}{c}\text { Oil coated mild steel } \\
\text { immersed in sea water }\end{array}$ & -0.611 & 3.779 & 9.524 & 9238 & $0.3538 \times 10^{-5}$ \\
\hline
\end{tabular}

It is observed from the Table 5 that when mild steel is immersed in sea water, the corrosion potential is $-0.875 \mathrm{~V} v s$. SCE; the $L P R$ value is $1630 \mathrm{Ohm} \cdot \mathrm{cm}^{2}$. The corrosion current value is $1.918 \times 10^{-5} \mathrm{~A} / \mathrm{cm}^{2}$. It is inferred from the Table 5, that in the presence of inhibitor (oil coated mild steel), the corrosion potential is shifted from $-0.875 \mathrm{~V}$ to $-0.611 \mathrm{~V}$ $v s$. SCE. This anodic shift indicates that the anodic reaction of metal dissolution $\left(\mathrm{Fe} \rightarrow \mathrm{Fe}^{2+}+2 \mathrm{e}^{-}\right)$in controlled predominantly in the presence the oil coating containing plant extracts. It is further noticed that the $L P R$ value increases (Figure 6) from $1630 \mathrm{Ohm} \cdot \mathrm{cm}^{2}$ to $9238 \mathrm{Ohm} \cdot \mathrm{cm}^{2}$. Correspondingly the corrosion current value decreases from $1.918 \times 10^{-5} \mathrm{~A} / \mathrm{cm}^{2}$ to $0.3538 \times 10^{-5} \mathrm{~A} / \mathrm{cm}^{2}$. These observations confirm that a protective film is formed on the metal surface. This controls the corrosion of metal. If a protective film is formed on the metal surface, $L P R$ value increases and corrosion current decreases. 


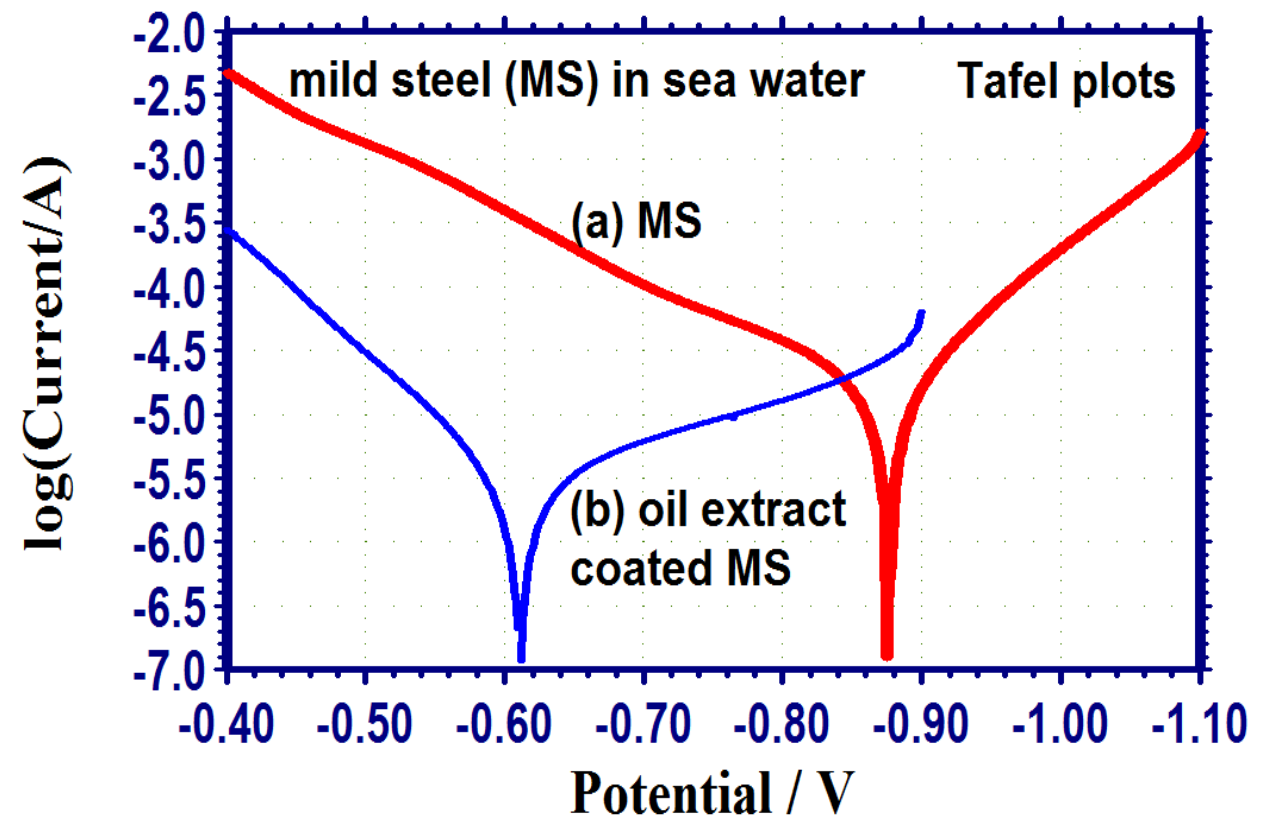

Figure 5. Polarisation curves of mild steel immersed in various test solutions: (a) MS in sea water, (b) oil extract coated MS in sea water.

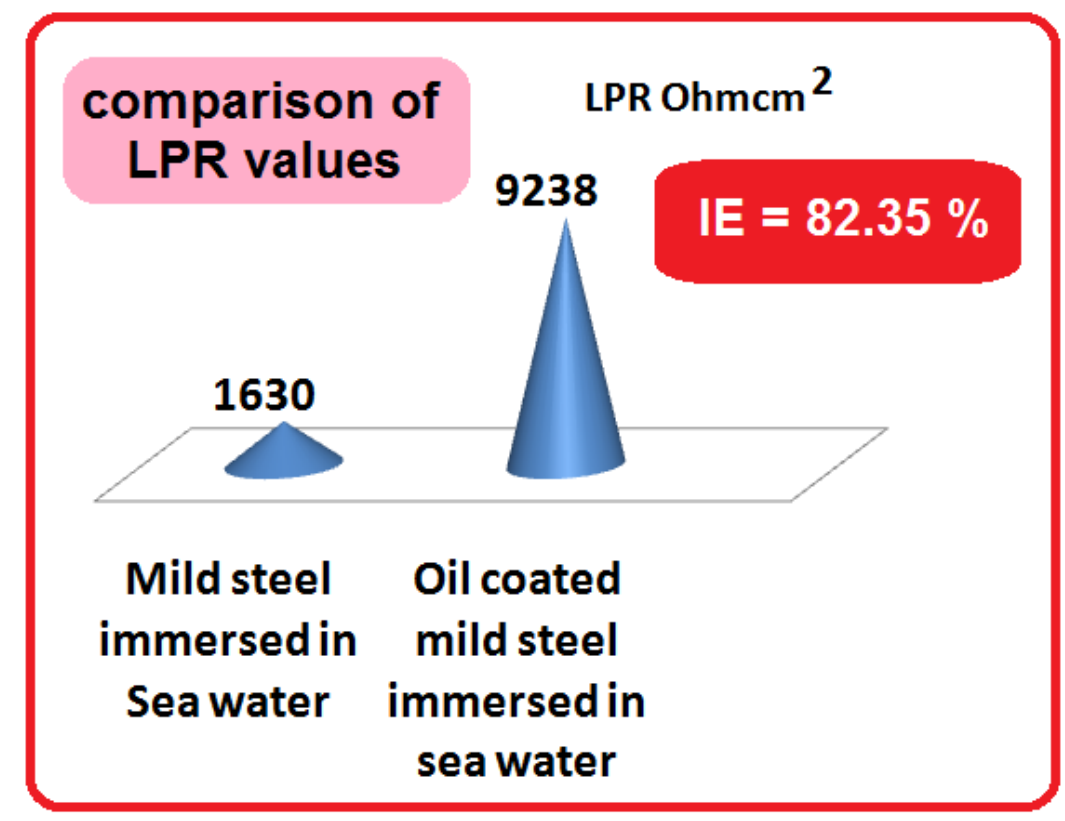

Figure 6. Comparison of $L P R$ values.

\section{Implication}

Polarization study leads to the conclusion that oil coated mild steel immersed in sea water is more corrosion resistant than bare mild steel in sea water. It implies that the hull plates may be coated with the oil containing plant extracts. 


\section{AC impedance spectra}

The protective film formed on the metal surface is confirmed by AC impedance spectra. If a protective film is formed on the metal surface, the charge transfer resistance $\left(R_{\mathrm{t}}\right)$ value increases; double layer capacitance value $\left(C_{\mathrm{dl}}\right)$ decreases and the impedance $[\log (\mathrm{Z} / \mathrm{Ohm})]$ value increases (Figure 7). The AC impedance spectra of mild steel (hull plate) immersed in sea water in the absence and presence of oil coating containing plant extract are shown in Figures 8 and 9. The AC impedance spectra of mild steel (hull plate) immersed in sea water in the absence and presence of oil coating containing plant extract are shown in Figure 8 (Nyquist plot), Figure 9 (Bode plots). The corrosion parameters, namely $R_{\mathrm{t}}, C_{\mathrm{dl}}$, and impedance values are given in Table 6 . It is observed from the Table 6 that, when mild steel is immersed in well water, the $R_{\mathrm{t}}$ value is $6.93 \mathrm{Ohm} \cdot \mathrm{cm}^{2}$. The $C_{\mathrm{dl}}$ value is $7.359 \times 10^{-7} \mathrm{~F} / \mathrm{cm}^{2}$. The impedance value is $1.114 \mathrm{Z} / \mathrm{Ohm}$. In the presence of inhibitor system, the $R_{\mathrm{t}}$ value increases (Figure 10) from $6.93 \mathrm{Ohm} \cdot \mathrm{cm}^{2}$ to $403.3 \mathrm{Ohm} \cdot \mathrm{cm}^{2}$. The $C_{\mathrm{dl}}$ value decreases from $7.359 \times 10^{-7} \mathrm{~F} / \mathrm{cm}^{2}$ to $0.1265 \times 10^{-7} \mathrm{~F} / \mathrm{cm}^{2}$. The impedance value increases from 1.114 to $2.65 \mathrm{Z} / \mathrm{Ohm}$.

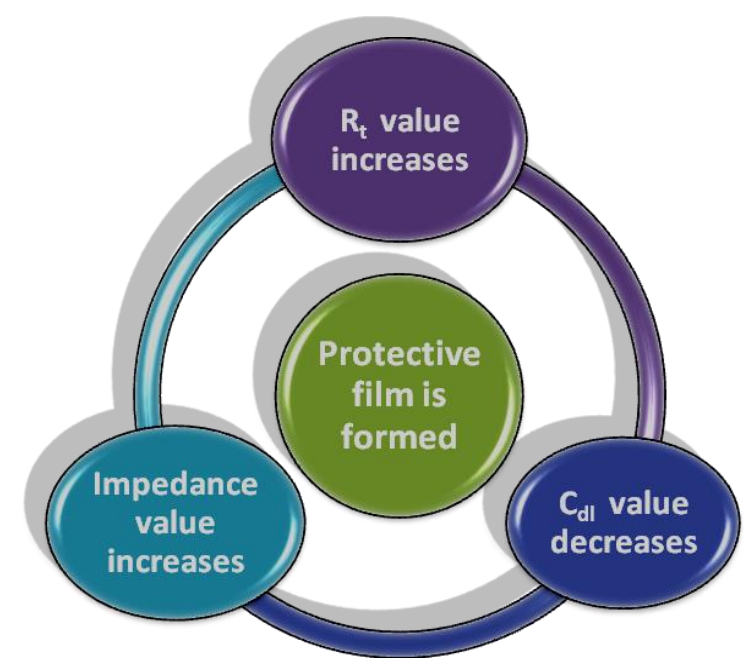

Figure 7. Relation among corrosion resistance and impedance parameters.

Table 6. Corrosion parameters of mild steel immersed in sea water obtained by AC impedance spectra.

\begin{tabular}{cccc}
\hline System & $\begin{array}{c}\boldsymbol{R} \mathbf{t} \\
\mathbf{O h m} \cdot \mathbf{c m}^{\mathbf{2}}\end{array}$ & $\begin{array}{c}\boldsymbol{C}_{\mathrm{dl}} \\
\mathbf{F} / \mathbf{c m}^{\mathbf{2}}\end{array}$ & $\begin{array}{c}\text { Impedance } \\
\mathbf{l o g}(\mathbf{Z} / \mathbf{O h m})\end{array}$ \\
\hline Mild steel immersed in sea water & 6.93 & $7.359 \times 10^{-7}$ & 1.114 \\
Oil extract coated mild steel immersed in sea water & 403.3 & $0.1265 \times 10^{-7}$ & 2.65 \\
\hline
\end{tabular}



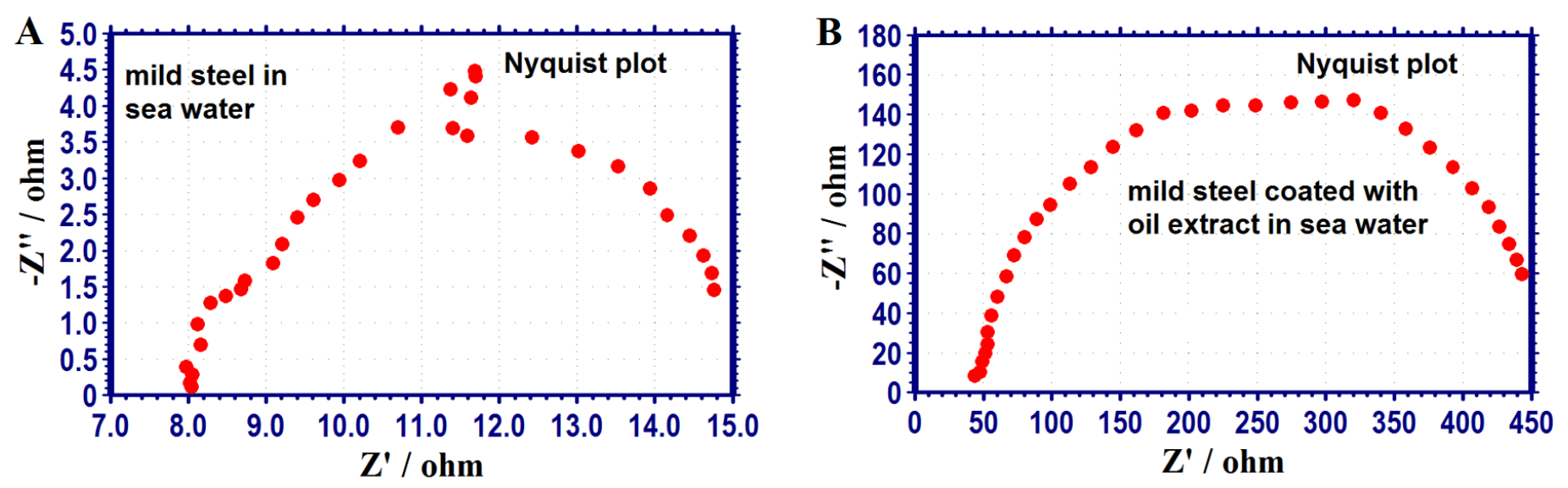

Figure 8. Nyquist plot of: A - mild steel immersed in sea water; B - oil extract coated mild steel immersed in sea water.
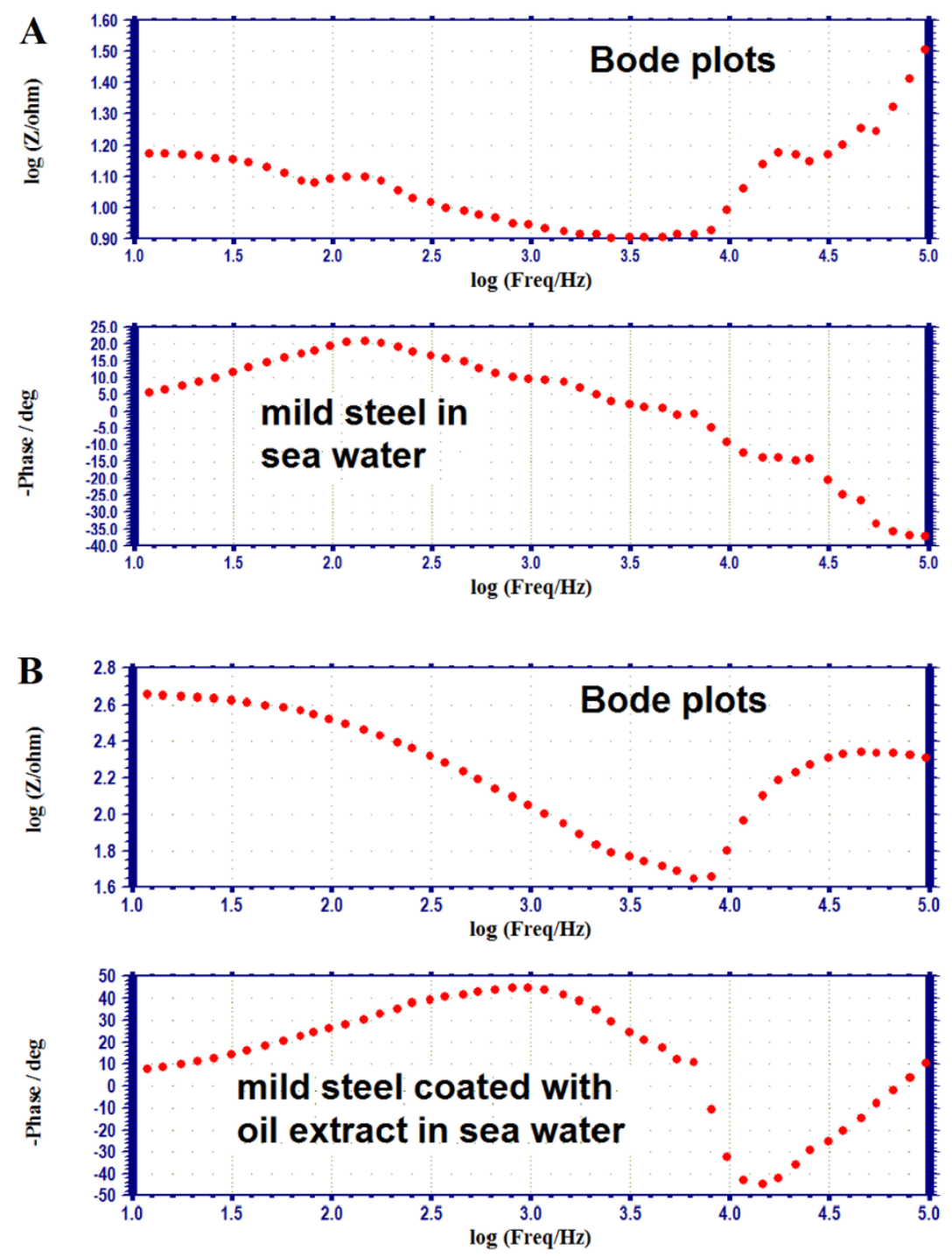

Figure 9. Bode plots of: A - mild steel immersed in sea water; B - oil extract coated mild steel immersed in sea water. 


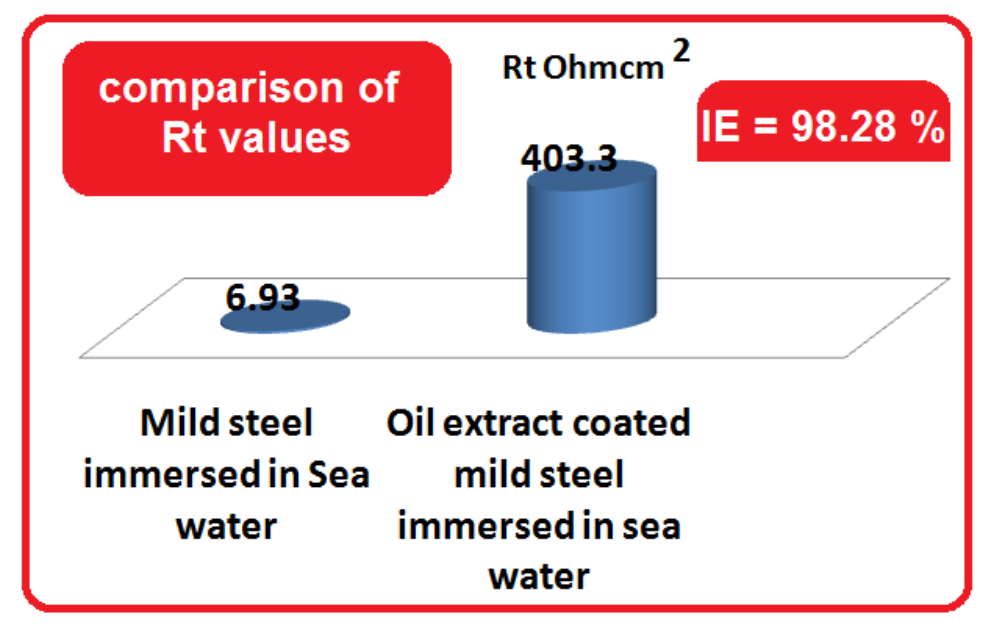

Figure 10. Comparison of $R_{\mathrm{t}}$ values.

\section{Implication}

AC impedance spectra lead to the conclusion that oil coated mild steel immersed in sea water is more corrosion resistant than bare mild steel in sea water. It implies that the hull plates, made of mild steel may be coated with the oil containing plant extracts to protect them from corrosion.

\section{Analysis of Vickers hardness}

The Vickers test is often easier to use than other hardness tests since the required calculations are independent of the size of the indenter, and the indenter can be used for all materials irrespective of hardness. The basic principle, as with all common measures of hardness, is to observe a material's ability to resist plastic deformation from a standard source. The Vickers test can be used for all metals and has one of the widest scales among hardness tests. The unit of hardness given by the test is known as the Vickers Pyramid Number (HV).

The hardness was measured for polished mild steel surface (system A), polished mild steel surface immersed in corrosive medium (sea water) (system B) and polished mild steel surface coated with oil containing plant extract, immersed in corrosive medium (sea water) (system C). The values are given in Tables 7 and 8 . It is observed that for system A the hardness is high. For system B the hardness is low because the corroded surface contains iron oxide film which is porous and amorphous. The surface is very rough. Pits are noticed due to corrosion. For system $\mathrm{C}$ the surface is smooth, due to the formation of protective film. Usually the hardness is in between that of system A and B. That is, lower than that of polished metal but higher than that of corroded surface (Figure 11). This is due to the formation of a protective film formed on the metal during corrosion inhibition process. The protective film consists of the paint coated on mild steel. Thus the Vickers hardness is used in corrosion inhibition study. Weight loss method reveals that the paint coating offers an inhibition efficiency of $99 \%$ to carbon steel immersed in sea water. 
Table 7. Hardness of various metal (mild steel-hull plate) surfaces.

\begin{tabular}{ccccccc}
\hline S. No. & System & S. No. & L1 & L2 & HV & $\begin{array}{c}\text { Average } \\
\text { hardness }\end{array}$ \\
\hline 1 & Unpolished metal & 1 & 44.65 & 48.27 & 85.8 & - \\
2 & Unpolished metal & 2 & 43.60 & 45.51 & 93.4 & 89.6 \\
3 & polished metal & 1 & 40.41 & 41.54 & 110 & - \\
4 & polished metal & 2 & 40.27 & 41.02 & 112 & 111 \\
5 & polished metal in sea water & 1 & 45.17 & 47.22 & 86.2 & - \\
6 & polished metal in sea water & 2 & 45.64 & 46.28 & 86.8 & 86.5 \\
7 & Polished metal with oil extract coating & 1 & 42.36 & 43.25 & 101 & - \\
8 & Polished metal with oil extract coating & 2 & 42.66 & 43.77 & 99.2 & 100.1 \\
\hline
\end{tabular}

Table 8. Summary of Hardness of various metal (mild steel-hull plate) surfaces.

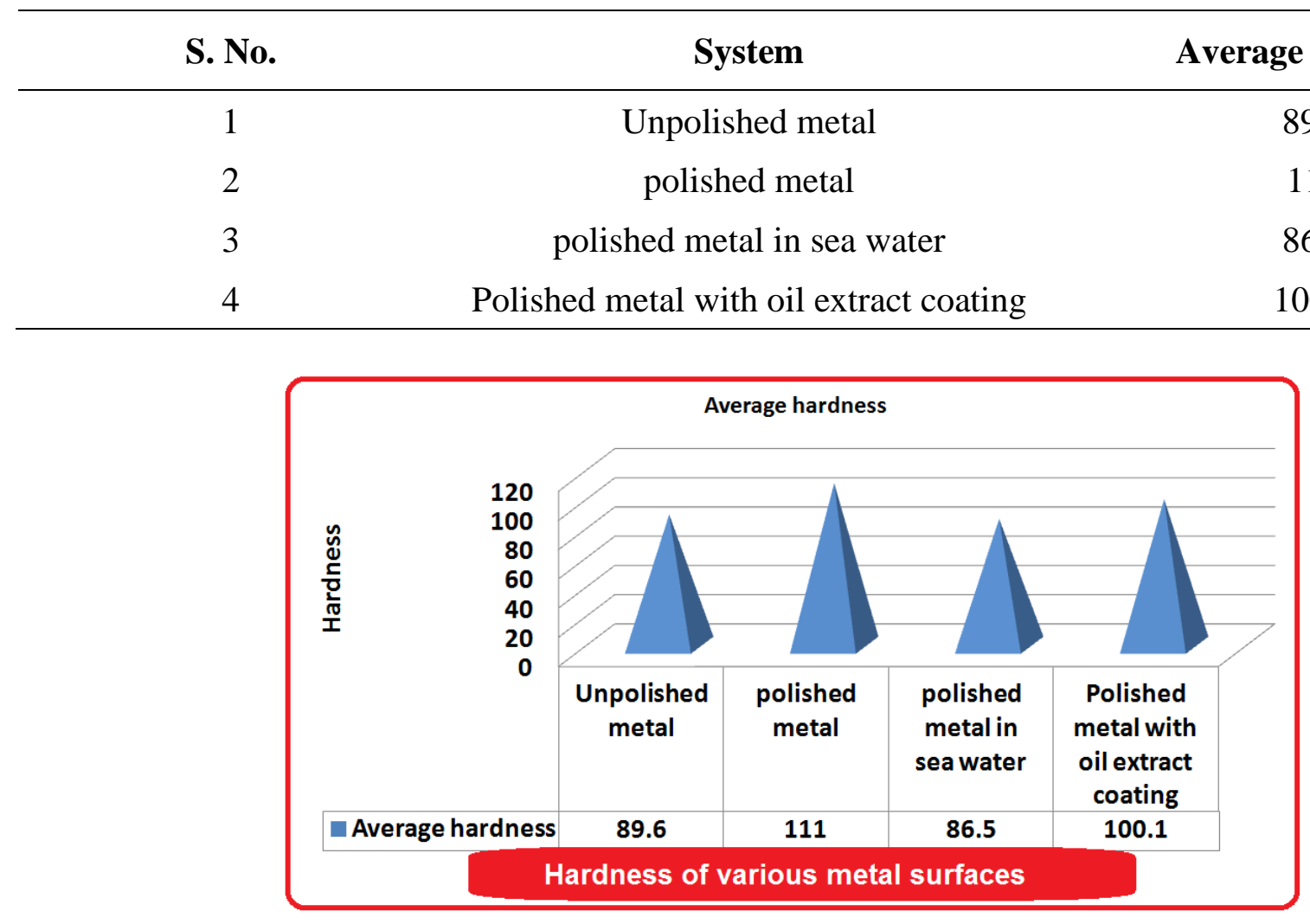

Figure 11. Harness of various metal surfaces.

It is noted from Figure 11 that the hardness of mild steel increases in the presence of oil coating. Hence such oil coating is recommended for hull plates to prevent them from corrosion caused by sea water. 


\section{Analysis of SEM images}

The surface morphology of various metal surfaces has been picturised by SEM images and they are anchored in images (Figure 12). It is interesting to note that pits are noticed on mild steel when it is immersed in sea water. However, the pits have disappeared when oil coating is given, and the metal is sea water. Because of the hydrophobic nature of the oil coating water cannot enter onto the metal surface. Thus corrosion of hull plates can be prevented.
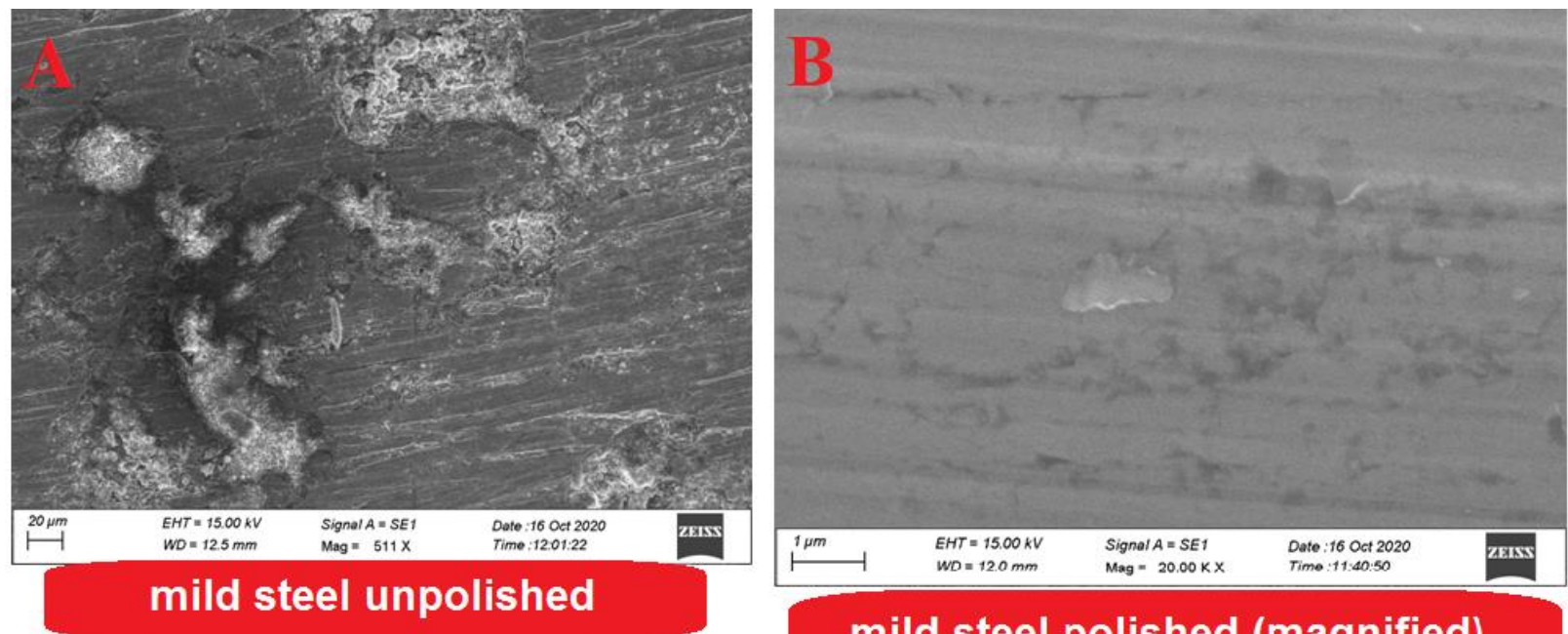

mild steel polished (magnified)
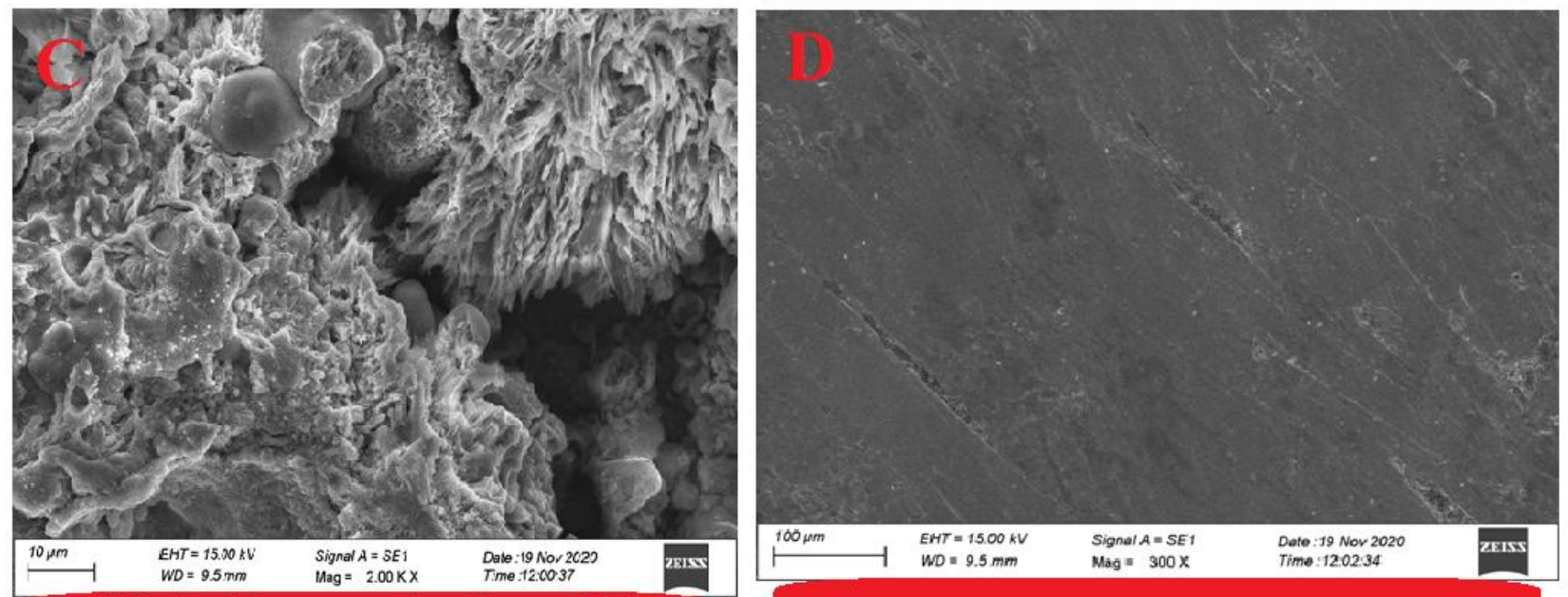

mild steel in sea water (magnified)

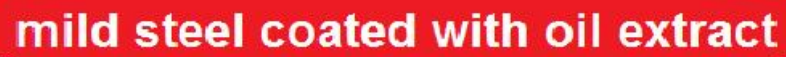

Figure 12. SEM image of: A - unpolished mild steel; B - upolished mild steel;

$\mathrm{C}$ - polished mild steel immersed in sea water; D - polished mild steel coated with oil extract and immersed in sea water.

\section{Contact angle measurements}

Contact angle measurements can be used to predict the hydrophobic nature of metal surfaces. When contact angle increases, hydrophobicity increases. This results in increase in corrosion inhibition efficiency (Figure 13). 


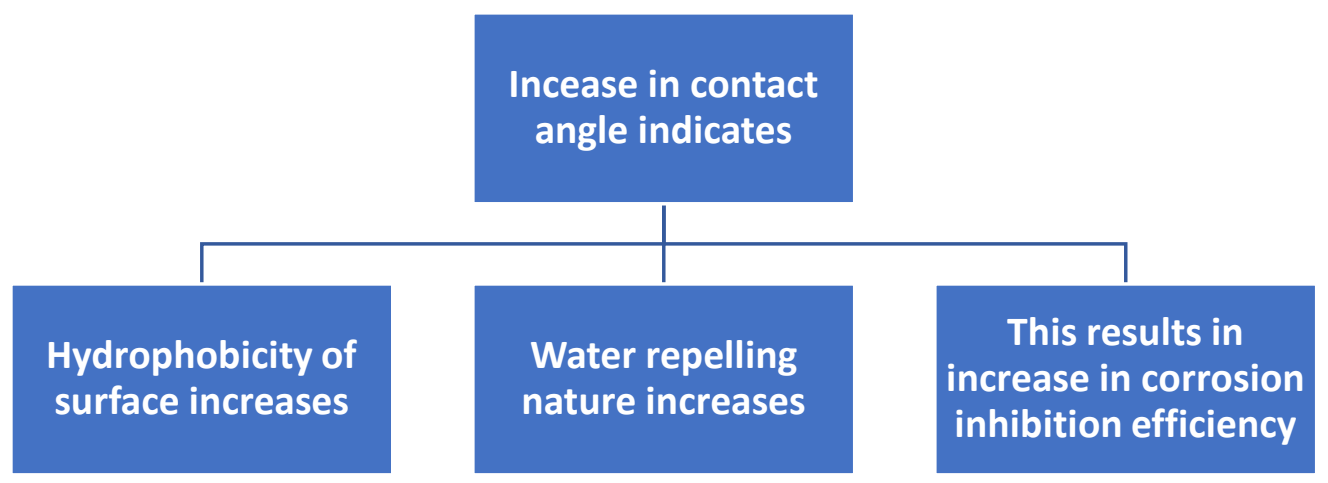

Figure 13. Contact angle and corrosion inhibition efficiency.

The contact angles of various metal surfaces are shown in Figure 14. For polished mild steel the contact angle is $108.5^{\circ}$. When mild steel is immersed in the corrosive medium the contact angle decreases to $23.6^{\circ}$. However, when oil coating is given the contact angle increases from $23.6^{\circ}$ to $74.3^{\circ}$. This results in very high corrosion inhibition efficiency, namely, $99 \%$ as revealed by weight loss method.

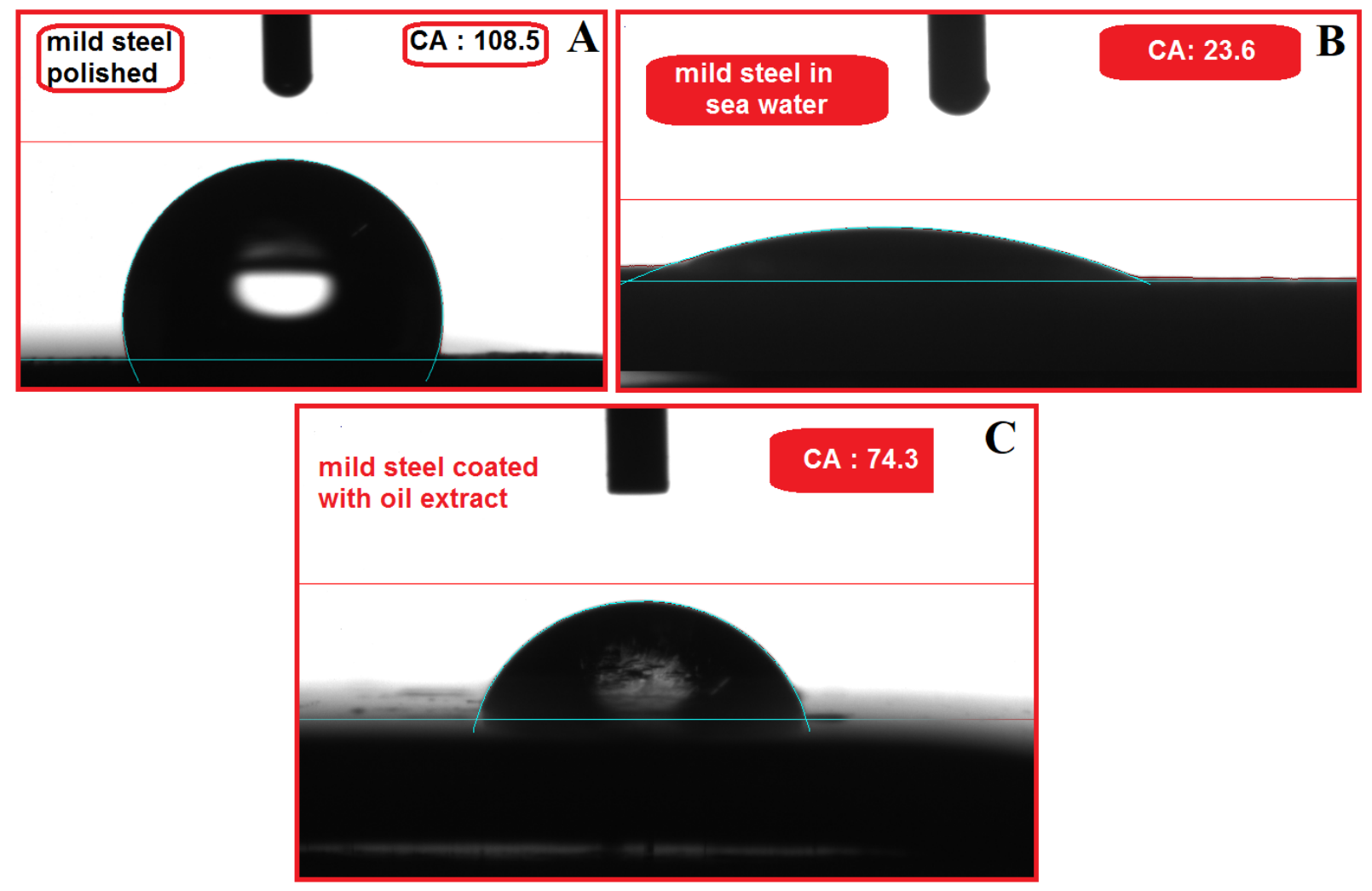

Figure 14. Contact angle of: $\mathrm{A}$ - polished mild steel surface; $\mathrm{B}$ - polished mild steel surface after immersion in sea water; $\mathrm{C}$ - polished oil coated mild steel surface after immersion in sea water. 
Analysis of results of FTIR spectra

$5 \mathrm{~g}$ of each Cardamom (dismbiguation), Clove (dismbiguation), Nutmeg, India Sambrani (loban), Chrysopogon zizanioides, commonly known as vetiver, and Camphor were boiled along with sandalwood oil for 15 minutes in an iron vessel. The suspended impurities were removed by filtration. The total volume of the oil extract of the above was $100 \mathrm{ml}$. This oil extract of the plant materials was used in the present study. The main active ingredients of the above materials are given in Table 3, and their structures are shown in Figure 1, in the experimental section.

FTIR spectra have been used to characterize the protective film formed on the metal surface. This protective film controls the corrosion of metal immersed in the corrosive medium, sea water in the present study.

An oil (sandalwood oil) extract of plant materials was coated on the metal surface. The oil extract was prepared by heating the shade dried plant materials such as, Cardamom, Clove, Nutmeg, vetiver and Camphor. The active principles of the oil extract contain the functional groups given in the Table 3.

In the FTIR spectral study, the following method was adopted. A few drops of the oil extract was placed on a glass plate and dried in the air. The film was carefully scratched with glass rod and mixed with $\mathrm{KBr}$ and made into a pellet. Its FTIR spectrum is shown in Figure 15. The stretching frequencies of various functional groups are shown in Table 9.

Table 9. FTIR stretching frequencies of functional groups.

\begin{tabular}{cccc}
\hline S. No. & Functional group & $\begin{array}{c}\text { Oil extract of natural } \\
\text { products (glass plate), } \\
\text { frequency, } \mathbf{~ m}^{-1}\end{array}$ & $\begin{array}{c}\text { Protective film on } \\
\text { metal surface, } \\
\text { frequency, } \mathbf{c m}^{-1}\end{array}$ \\
\hline 1 & Cyclohexene & $1650 \mathrm{C}=\mathrm{C}$ & 1630.4 \\
2 & Cyclohexane & 2925 & 2926 \\
3 & $-\mathrm{CH}_{3}$ Aliphatic C-H & $2925.58,2854.49$ & 2926,2855 \\
4 & $-\mathrm{OH}$ & 3437.113436 & 3437 \\
5 & $-\mathrm{O}-$ Ether aliphatic & 1119.2 & 1116 \\
6 & Benzene, aromatic ring C C & 1746 & 1746 \\
7 & Aliphatic C=C & 1630 & 1630.4 \\
8 & Aliphatic aromatic ether & $1240,1162,1119,1036$ & $1164,1116,1024$ \\
9 & C=O carboxyl group & 1746 & 1744 \\
10 & C=O & 1746 & 1744 \\
\hline
\end{tabular}

In the next stage, the meal was immersed in the oil extract for one day. After one day, the meal was taken out and dried. The film formed on the metal surface was carefully scratched with glass rod and mixed with $\mathrm{KBr}$ and made into a pellet. Its FTIR spectrum is 
shown in Figure 16. The stretching frequencies of various functional groups are shown in Table 9. There is shift in the position of the frequencies of the various functional groups. This suggests that the active principles present in the oil extract have combined with $\mathrm{Fe}^{2+}$ on the metal surface forming the protective film. Thus it is inferred that the protective film consists of $\mathrm{Fe}^{2+}$ - active principle complexes, formed on the metal surface.

The FTIR spectrum of the metal surface immersed in the corrosive medium namely sea water (SW) is shown in Figure 17. The peaks indicate the presence of various oxides of iron $[31,32]$. Surprisingly the magnetic oxide of iron, $\mathrm{Fe}_{3} \mathrm{O}_{4}$, is present as nanoparticles. This layer is very close to the iron surface; next comes the $\alpha-\mathrm{FeOOH}$ layer and then $\mathrm{FeOOH}$ layer present on the upper layer of the cannon. Similar observation is made in the case of Delhi iron pillar also.

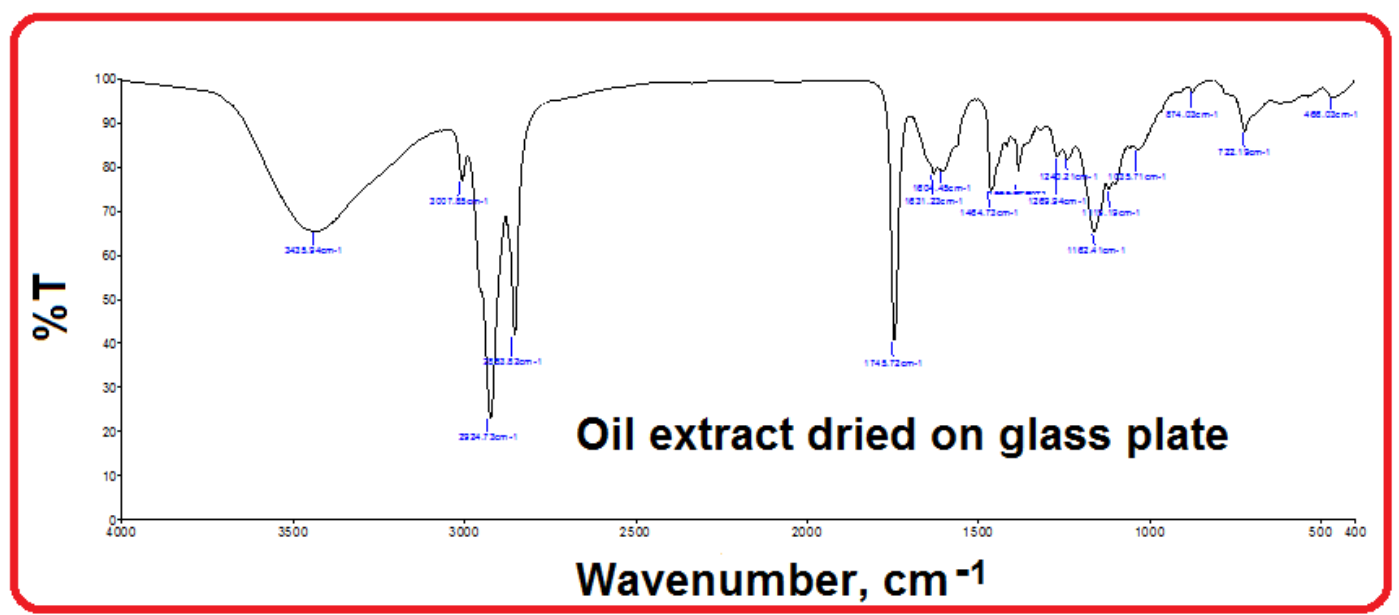

Figure 15. FTIR spectrum of oil extract dried on glass plate.

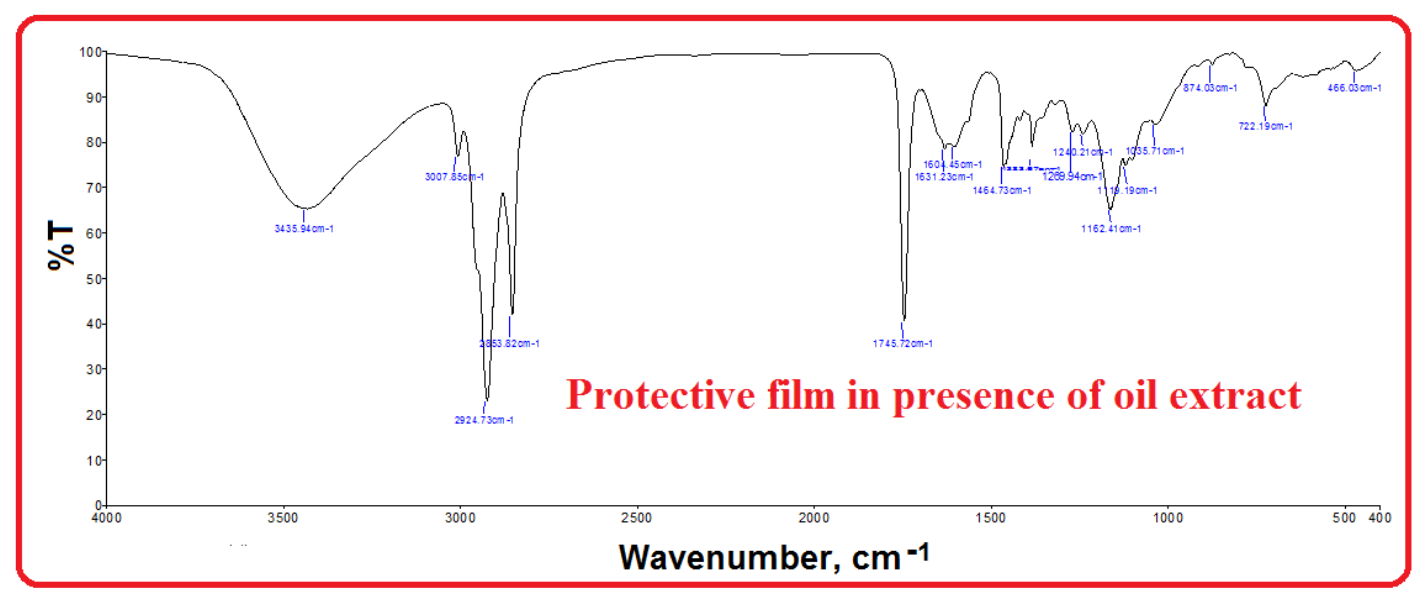

Figure 16. FTIR spectrum of protective film. 


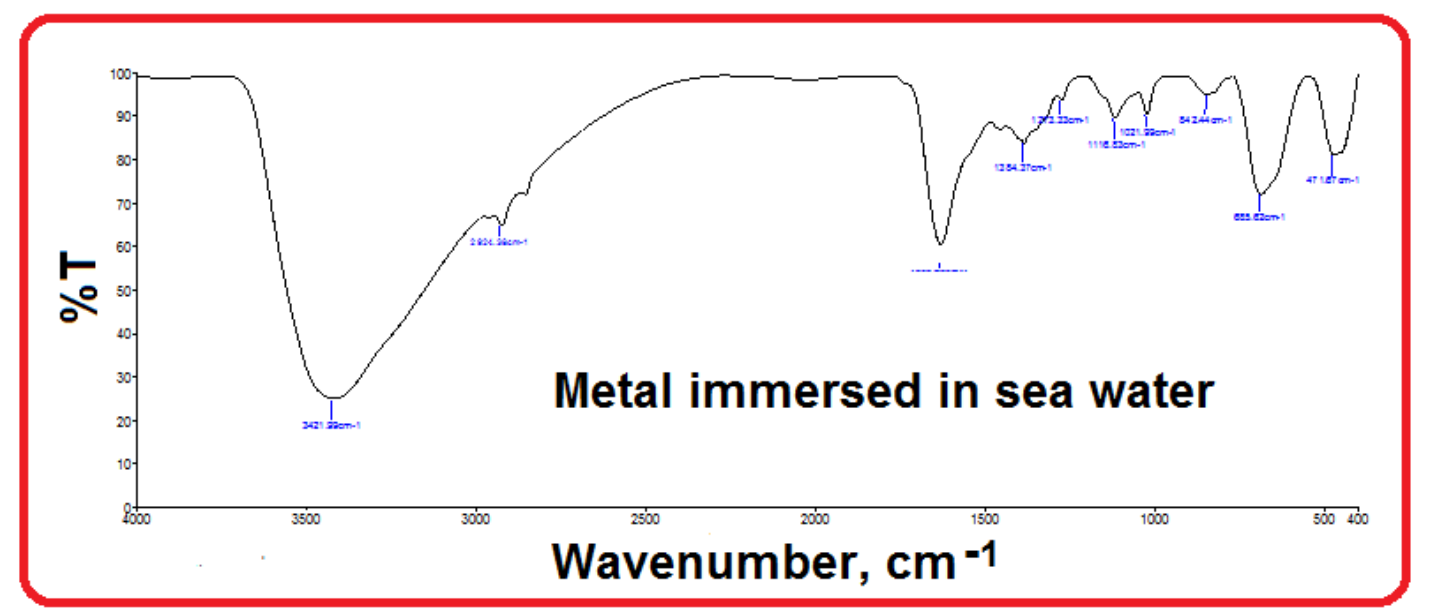

Figure 17. FTIR spectrum of mild steel immersed in sea water (oxides of iron).

The peak at $686 \mathrm{~cm}^{-1}$ is due to the iron-oxygen bond. The peaks due to magnetic iron oxide $\left(\mathrm{Fe}_{3} \mathrm{O}_{4}\right)$ nanoparticles appear at $3422,1633,1022 \mathrm{~cm}^{-1}[31,32]$.

Table 10. FTIR stretching frequencies of iron oxides.

\begin{tabular}{ccc}
\hline S. No. & Iron oxide & Frequency, $\mathbf{c m}^{\mathbf{- 1}}$ \\
\hline 1 & $\mathrm{FeOOH}$ & 472,1022 \\
2 & $\mathrm{Fe}_{3} \mathrm{O}_{4}$ & $2924,1384,1022$ \\
3 & $\alpha-\mathrm{Fe}_{2} \mathrm{O}_{3}$ & 1633 \\
4 & Iron-oxygen bond & 686 \\
5 & Magnetic iron oxide & $3422,1633,1022$ \\
\hline
\end{tabular}

\section{Conclusions}

- Mild steel can be used as hull plates in ship industry. Mild steel has to be in contact with sea water which contains aggressive sodium chloride ions to the extent of $3.5 \%$. This leads to severe corrosion problems.

- To mitigate this corrosion problem an oil coating containing extracts of natural products was used.

- The corrosion protection nature of this oil coating has been evaluated by weight loss method which reveals that the oil coating offers $99 \%$ inhibition efficiency to mild steel immersed in natural sea water.

- The polarization study reveals that the coating acts as a barrier film controlling the anodic reaction predominantly. The corrosion potential is shifted from $-0.875 \mathrm{~V}$ SCE to $-0.611 \mathrm{~V}$ SCE. The linear polarization value increases from $1630 \mathrm{Ohm} \cdot \mathrm{cm}^{2}$ to $9238 \mathrm{Ohm} \cdot \mathrm{cm}^{2}$. The corrosion current decreases from $1.918 \times 10^{-5} \mathrm{~A} / \mathrm{cm}^{2}$ to 
$0.3538 \times 10^{-5} \mathrm{~A} / \mathrm{cm}^{2}$. These factors confirm that the oil coating controls the corrosion of hull plates in sea water.

- The AC impedance spectra confirm that the protective coating is very stable as revealed by the fact that in the presence of coating on mild steel, its charge transfer resistance increases and impedance increases, whereas corrosion current decreases to a great extent.

- Vickers hardness study confirms that in the presence of sea water, the hardness of mild steel decreases whereas in the presence of coating the hardness of mild steel increases.

- SEM images of various metal surfaces reveal that in the presence of sea water alone, pits are noticed on mild steel whereas in the presence of oil coating the surface appears to be smooth, when immersed in sea water.

- When mild steel is immersed in sea water, the contact angle decreases when compared with polished metal. But for oil coated mild steel the contact angle increases, hydrophobicity increases and hence corrosion protection increases.

- It is suggested that this oil coating containing extracts of plant material may be coated on hull plates made of mild steel to protect them from severe corrosion due to the aggressive ions present in sea water.

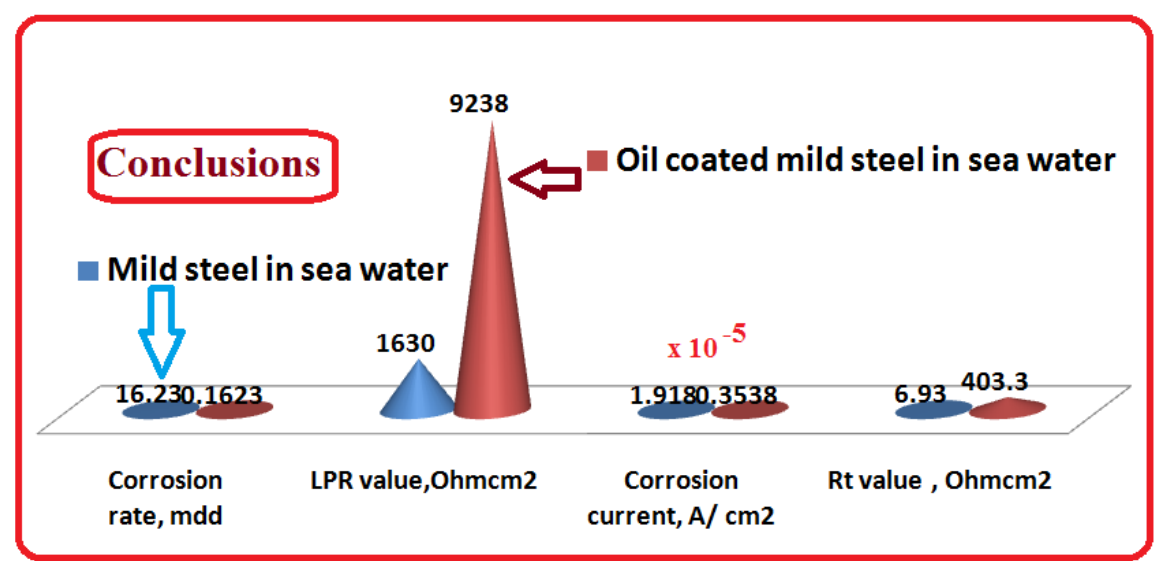

Figure 18. Conclusions 1.

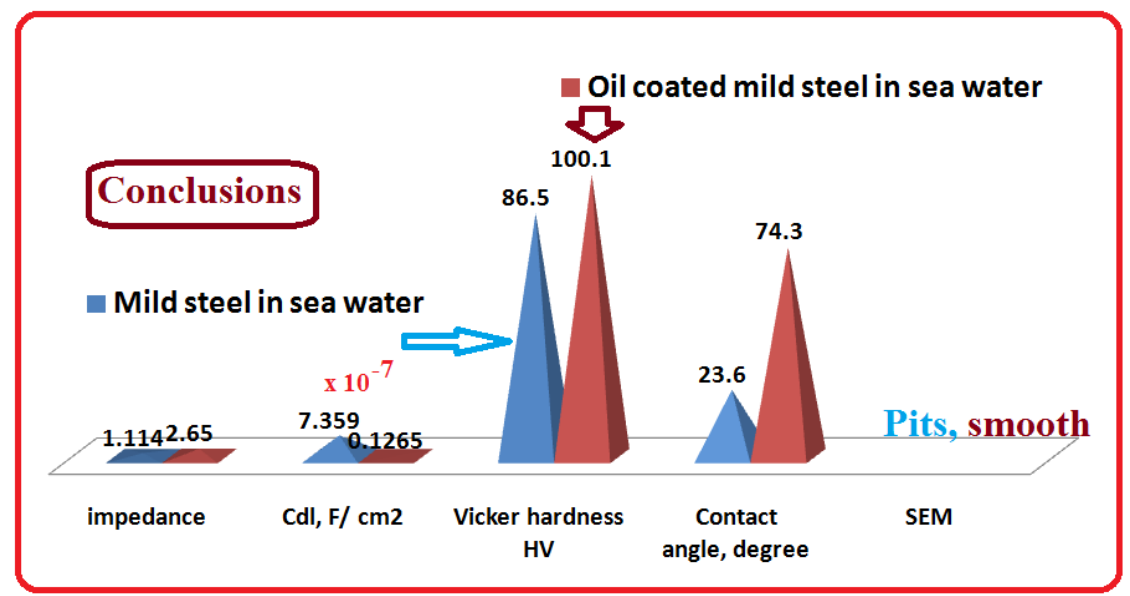

Figure 19. Conclusions 2. 


\section{References}

1. Y. Shen, Y. Dong, Y. Yang, Q. Li, H. Zhu, W. Zhang, L. Dong and Y. Yin, Study of pitting corrosion inhibition effect on aluminum alloy in seawater by biomineralized film, Bioelectrochemistry, 2020, 132, 107408. doi: 10.1016/j.bioelechem.2019.107408

2. Q. Xu, T. Ji, Z. Yang and Y. Ye, Steel rebar corrosion in artificial reef concrete with sulphoaluminate cement, Constr. Build. Mater., 2019, 227, 116685.

3. S. Elbasuney, M. Gobara, M. Zoriany, A. Maraden and I. Naeem, The significant role of stabilized colloidal $\mathrm{ZrO}_{2}$ nanoparticles for corrosion protection of AA2024, Environmental Nanotechnology Monitoring and Management, 2019, 12, 100242. doi: 10.1016/j.enmm.2019.100242

4. E. Plaskeeva and V. Trusov, Inhibited composition for work in marine conditions, E3S Web Conf., 2019, 121, 02011. doi: 10.1051/e3sconf/20191210201

5. W.E. Duduna, O.N. Akeme and T.M. Zinipere, Comparison of various adsorption isotherm models for allium cepa as corrosion inhibitor on austenitic stainless steel in sea water, Int. J. Sci. Technol. Res., 2019, 8, no. 8, 961-964.

6. S. Karthikeyan and P.A. Jeeva, Corrosion studies of zinc coated steel parts in sea water, Port. Electrochim. Acta, 2019, 37, no. 5, 307-315. doi: 10.4152/pea.201905307

7. M. Schorr, B. Valdez, A. Eliezer, R. Salinas and C. Lora, Managing corrosion in desalination plants, Corros. Rev., 2019, 37, no. 2, 103-113. doi: 10.1515/corrrev-2018$\underline{0038}$

8. B. Da, H. Yu, H. Ma and Z. Wu, Influence of inhibitors on reinforced bar corrosion of coral aggregate seawater concrete, J. Chinese Soc. Corros. Prot., 2019, 39, no. 2, $152-159$.

9. A.H. Ahmad, R.M. Kubba and S.M. Hussain Al-Majidi, Synthesis, identification, theoretical and experimental studies for carbon steel corrosion inhibition in sea water for new urea and thiourea derivatives linkage to 5-Nitro Isatin Moiety, Pharma Chem., 2018, 10, no. 7, 86-99.

10. I.H. Ali, A.M. Idris and M.H.A. Suliman, Evaluation of leaf and bark extracts of Acacia tortilis as corrosion inhibitors for mild steel in seawater: Experimental and studies, Int. J. Electrochem. Sci., 2019, 14, 6406-6419. doi: 10.20964/2019.07.10

11. S. Rajendran, M.K. Devi, A.P.P. Regis, A.J. Amalraj, J. Jeyasundari and M. Manivannan, Electroplating using environmental friendly garlic extract: a case study, Zast. Mater., 2009, 50, 131-140.

12. S. Rajendran, P. Chitradevi, S. Johnmary, A. Krishnaveni, S. Kanchana, L. Christy, R. Nagalakshmi and B. Narayanasamy, Corrosion behaviour of SS 316L in artificial saliva in the presence of electral, Zast. Mater., 2010, 51, 149-158.

13. S. Rajendran, M. Agasta, R.B. Devi, B.S. Devi, K. Rajam and J. Jeyasundari, Corrosion inhibition by an aqueous extract of Henna leaves (Lawsonia Inermis L), Zast. Mater., 2009, 50, 77-84. 
14. A.C.C. Mary, S. Rajendran and J. Jeyasundari, Influence of Coffee on the corrosion resistance of SS 316L, Ni-Ti alloy and thermoactive alloy in artificial saliva, Eur. Chem. Bull., 2017, 6, 232-237.

15. V. Sribharathy, S. Rajendran, P. Rengan and R. Nagalakshmi, Corrosion inhibition by an aqueous extract of Aloe vera (L) Burm F. (Liliaceae), Eur. Chem. Bull., 2013, 2, 471-476. doi: 10.17628/ecb.2013.2.471-476

16. R. Epshiba, A.P.P. Regis and S. Rajendran, Inhibition of corrosion of carbon steel in a well water by sodium molybdate $-\mathrm{Zn}^{2+}$ system, Int. J. Nano Corros. Sci. Eng., 2014, 1, $1-11$.

17. N. Kavitha and P. Manjula, Corrosion inhibition of water Hyacinth Leaves, $\mathrm{Zn}^{2+}$ and TSC on mild steel in neutral aqueous medium, Int. J. Nano Corros. Sci. Eng., 2014, 1, 31-38.

18. R. Nagalakshmi, L. Nagarajan, R.J. Rathish, S.S. Prabha, N. Vijaya, J. Jeyasundari and S. Rajendran, Corrosion resistance of SS3161 in artificial urine in the presence of D-glucose, Int. J. Nano Corros. Sci. Eng., 2014, 1, 39-49.

19. J.A. Thangakani, S. Rajendran, J. Sathiabama, R.M. Joany, R.J. Rathis and S.S. Prabha, Inhibition of corrosion of carbon steel in aqueous solution containing low chloride ion by glycine $-\mathrm{Zn}^{2+}$ system, Int. J. Nano Corros. Sci. Eng., 2014, 1, 50-62.

20. S. Gowri, J. Sathiyabama, S. Rajendran and J.A. Thangakani, Typtophane as corrosion inhibitor for carbon steel in sea water, J. Chem., Biol. Phys. Sci., 2012, 4, no. 2, $2223-$ 2231.

21. A. Nithya, P. Shanthy, N. Vijaya, R.J. Rathish, S.S. Prabha, R.M. Joany and S. Rajendran, Inhibition of Corrosion of Aluminium by an aqueous extract of beetroot (Betanin), Int. J. Nano Corr. Sci. Eng., 2015, 2, no. 1, 1-11.

22. A.C.C. Mary, S. Rajendran, H. Al-Hashem, R.J. Rathish, T. Umasankareswari and J. Jeyasundari, Corrosion Resistance Of Mild Steel In Simulated Produced Water In Presence Of Sodium Potassium Tartrate, Int. J. Nano Corr. Sci. Eng., 2015, 2, no. 1, 4250.

23. A. Anandan, S. Rajendran, J. Sathiyabama and D. Sathiyaraj, Influence of some tablets on corrosion resistance of orthodontic wire made of SS 316L alloy in artificial saliva, Int. J. Corros. Scale Inhib., 2017, 6, no. 2, 132-141. doi: 10.17675/2305-6894-2017-6$\underline{2-3}$

24. C.O. Akalezi, C.E. Ogukwe, E.A. Ejele and E.E. Oguzie, Mild steel protection in acidic media using Mucuna pruriens seed extract, Int. J. Corros. Scale Inhib., 2016, 5, no. 2, 132-146. doi: $10.17675 / 2305-6894-2016-5-2-3$

25. T.A. Onat, D. Yiğit, H. Nazır, M. Güllü and G. Dönmez, Biocorrosion inhibition effect of 2-aminopyrimidine derivativeson SRB, Int. J. Corros. Scale Inhib., 2016, 5, no. 3, 273-281. doi: 10.17675/2305-6894-2016-5-3-7

26. A.S. Fouda, M.A. El-Morsy, A.A. El-Barbary and L.E. Lamloum, Study on corrosion inhibition efficiency of some quinazoline derivatives on stainless steel 304 in 
hydrochloric acid solutions, Int. J. Corros. Scale Inhib., 2016, 5, no. 2, 112-131. doi: 10.17675/2305-6894-2016-5-2-2

27. V.I. Vigdorovich, L.E. Tsygankova, E.D. Tanygina, A.Yu. Tanygin and N.V. Shel, Preservative materials based on vegetable oils for steel protection against atmospheric corrosion. I. Colza oil, Int. J. Corros. Scale Inhib., 2016, 5, no. 1, 59-65. doi: 10.17675/2305-6894-2016-5-1-5

28. P.N. Devi, J. Sathiyabama and S. Rajendran, Study of surface morphology and inhibition efficiency of mild steel in simulated concrete pore solution by lactic acid $-\mathrm{Zn}^{2+}$ system, Int. J. Corros. Scale Inhib., 2017, 6, no. 1, 18-31. doi:10.17675/2305-6894-2017-6-1-2

29. I.M. Zin, S.A. Korniy, A.R. Kytsya, L. Kwiatkowski, P.Ya. Lyutyy and Ya.I. Zin, Aluminium alloy corrosion inhibition by pigments based on ion exchanged zeolite, Int. J. Corros. Scale Inhib., 2021, 10, no. 2, 541-550.doi:10.17675/2305-6894-2021-10-2-3

30. L.G. Knyazeva, L.E. Tsygankova, A.V. Dorokhov and N.A. Kur'yato, Protective efficiency of oil compositions with Cortec VpCI-368D, Int. J. Corros. Scale Inhib., 2021, 10, no. 2, 551-561.

31. M. Favre and D. Landolt, The influence of gallic acid on the reduction of rust on painted steel surfaces, ChemInform Abstr., 1993, 24, no. 48, 1481-1494. doi: 10.1002/chin.199348019

32. S. Rajendran, S. Thilak Kumar, S. Abuthahir and C. Sobiga, Cannons of dindigul fortA marvel of Indian metallurgical skill, J. Chem. Pharm. Sci., 2016, 9, no. 1, 166-168. 